\title{
PHYTOCHEMICAL ANALYSIS AND ANTIOXIDANT ACTIVITY OF METHANOLIC EXTRACT OF LEAVES OF CORCHORUS OLITORIUS
}

\author{
ABDUL SADAT ${ }^{1,3}$, MAYUKH HORE², KAUSHIK CHAKRABORTY ${ }^{3}$, SUBHRAJYOTI ROY2*
}

${ }^{1}$ Department of Sericulture, Raiganj University, Raiganj 733134, West Bengal, India, ${ }^{2}$ Immunopharmacology and Molecular Cell Biology Laboratory, Department of Zoology, University of Gour Banga, Malda 732103, West Bengal, India, ${ }^{3}$ Entomology Laboratory, Department of Zoology, University of Gour Banga, Malda 732103, West Bangal, India

Email: subhrajyoti_roy@rediff.com

Received: 21 May 2017, Revised and Accepted: 22 Jul 2017

\section{ABSTRACT}

Objective: The present study was carried out to evaluate the in vitro preliminary phytochemical analysis and antioxidant activity of methanolic leaf extracts of Corchorus olitorius L. The in vitro antioxidant activity was evaluated by DPPH radical scavenging activity method.

Methods: Fresh jute leaves (immature, mature and senescence) were collected, air dried and the crude powder was prepared for phytochemical and antioxidant analysis. The powder was mixed with $70 \%$ methanol and the supernatant was separated. The antioxidant activity of this methanolic extract was measured on the basis of the scavenging activity of the stable 1, 1-diphenyl 2-picrylhydrazyl (DPPH) free radical with slight modifications. Phytochemical analysis was performed according to standard laboratory protocol.

Results: The results indicated the presence of different phytochemicals viz. glycosides, steroids, cholesterol, alkaloids, phenols, flavonoids, riboflavin, saponins and terpenoids. The sample also showed antioxidant activity by inhibiting DPPH radical. The significant antioxidant activity of methanolic leaf extract of might be due to the presence of saponins, phenols, flavonoids and alkaloids found in the preliminary phytochemical analysis.

Conclusion: Present study reveals that the jute leaf possesses different phytonutrients and exhibited DPPH radical scavenging activity, and therefore, may be used for therapeutic purposes.

Keywords: Antioxidant activity, Corchorus olitorius, DPPH, Phytochemicals

(C) 2017 The Authors. Published by Innovare Academic Sciences Pvt Ltd. This is an open access article under the CC BY license (http://creativecommons.org/licenses/by/4.0/] DOI: http://dx.doi.org/10.22159/ijcpr.2017v9i5.22138

\section{INTRODUCTION}

Phytochemicals are known to work as immunomodulators and may have anti-inflammatory, anticancer and antimicrobial activities. All these properties of the phytochemicals are attributed to its effective antioxidant mechanisms against the endogenously produced harmful free radicals. Our body has effective antioxidant defence systems, which constitute enzymes, such as superoxide dismutase (SOD), catalase and compounds, such as ascorbic acid, tocopherol, and glutathione [1]. But all these endogenous antioxidants are not sufficient in protecting the body against oxidative stress. Therefore, dietary supplementation through natural antioxidants in place of synthetic antioxidants is necessary for strengthening the antioxidant system of the body by inhibiting free radical generation and thus preventing chronic diseases. Recently, much attention has been directed towards exploring natural antioxidants because they are natural products that are considered to be a safe source [2].

The plant Corchorus olitorius L. (Family-Tiliaceae), commonly known as jute plant, is an economically important fibre crop of India and elsewhere in the world. The plant is widely distributed in the tropics of both the hemisphere [3, 4]. Jute is cultivated in India, Bangladesh, Myanmar, Nepal, China, Taiwan, Thailand, Vietnam, Cambodia, Brazil and many other countries. Jute leaf is used as a herb in Middle Eastern and African countries. The use of jute leaf as traditional medicine by the Egyptian and Indian dated back to some $2500 \mathrm{y}$. They used it to treat fever, laryngitis, diarrhea and vomiting $[4,5]$. Thus, from the ancient time jute leaf was used in traditional medicine, but without knowing its actual curative source. Therefore, the aim of the present study is to determine the phytochemical constituents of Corchorus olitorius and in vitro antioxidant activity to correlate the rationale of their medicinal/ pharmacological uses to their phytochemical constituents.

\section{MATERIALS AND METHODS}

\section{Plant material and sample preparation}

Young (light green), mature (dark green) and senescence (yellow) $C$. olitorius leaves of 60DAS (Day after sowing) were collected from
Subhashganj area of Raiganj, West Bengal, India. The leaves were first washed in tap water and then in double distilled water to remove dirt. The leaves were then dried at room temperature for seven days, finely powdered and used for phytochemical analysis.

This dried powdered material was also used for solvent extraction for the preparation of sample required for the determination of antioxidant activity. The powder $(100 \mathrm{~g})$ was mixed with $500 \mathrm{ml}$ methanol: water (7:3) using a shaker for $15 \mathrm{~h}$; then the mixture was centrifuged at $2850 \times \mathrm{g}$ and the supernatant was decanted. The pellet was mixed again with $500 \mathrm{ml}$ methanol-water and the entire process was repeated once again, i.e., the extraction procedure was done twice. The supernatants collected from the two phases were mixed in a round-bottom flask and concentrated under reduced pressure in a rotary evaporator. The residue was used in the analysis of the antioxidant activity of $C$. olitorius.

\section{Qualitative tests}

The qualitative tests for phytochemicals were performed according to several previously published standard protocols [6-9].

$10 \mathrm{gm}$ of powdered material was mixed in $100 \mathrm{ml}$ of double distilled water and the mixture was placed in magnetic stirrer for $10 \mathrm{~h}$. The mixture was filtered through Whatman filter paper No. 1 and the filtrate was used for the following phytochemical tests.

Test for tannins: About $10 \mathrm{ml}$ of the aqueous extract was mixed with a few drops of $0.1 \%$ ferric chloride solution. Formation of a brownish-green or a blue-black precipitation indicated the presence of tannin.

Test for phlobatannins: $2 \mathrm{ml}$ of concentrated $\mathrm{HCl}$ was added to 10 $\mathrm{ml}$ of aqueous extract and boiled for $2 \mathrm{~min}$. Formation of red precipitate indicated the presence of phlobatannins.

Test for carbohydrates: $2 \mathrm{ml}$ of aqueous extract was mixed with Molish's reagent ( $5 \% \alpha$-napthol in absolute alcohol) and shaken vigorously. Then $2 \mathrm{ml}$ of concentrated $\mathrm{H}_{2} \mathrm{SO}_{4}$ was added carefully 
along the wall of the test tube. Formation of the reddish-violate ring at the junction of the liquid indicated the presence of carbohydrates.

Test for proteins: $2 \mathrm{ml}$ of aqueous extract was mixed with $1 \mathrm{ml}$ of $40 \% \mathrm{NaOH}$. Then 1-2 drop of $2 \% \mathrm{CuSO}_{4}$ added to the solution. Change in the colouration of the solution into violet indicated the presence of peptide linkage in a solution which in turn is an indication of the presence of protein.

$10 \mathrm{gm}$ of powdered sample was taken in $250 \mathrm{ml}$ conical flask and mixed with $100 \mathrm{ml}$ of $70 \%$ methanol and stirred in a magnetic stirrer for $10 \mathrm{~h}$ at room temperature. The mixture was then filtered through Whatman filter paper No. 1 and the filtrate was used for the following phytochemical tests.

Test for terpenoids: $5 \mathrm{ml}$ of methanolic leaf extract was added with $2 \mathrm{ml}$ of chloroform and then $3 \mathrm{ml}$ of concentrated $\mathrm{H}_{2} \mathrm{SO}_{4}$ was added carefully along the wall of the test tube to form a layer. Formation of reddish-brown colouration at the junction of two liquid indicated the presence of terpenoids.

Test for cardiac glycosides: $5 \mathrm{ml}$ of methanolic extracts was mixed with $2 \mathrm{ml}$ of glacial acetic acid containing one drop of $2 \%$ ferric chloride solution. Then $1 \mathrm{ml}$ of concentrated $\mathrm{H}_{2} \mathrm{SO}_{4}$ was added carefully along the wall of the test tube. Formation of a brown ring at the interface of the two liquids indicated the presence of glycosides.

Test for steroids: $5 \mathrm{ml}$ of sample extract was added with $0.5 \mathrm{ml}$ anhydrous $\mathrm{CH}_{3} \mathrm{COOH}$ and cooled in ice bath for $15 \mathrm{~min}$. After that 0.5 $\mathrm{ml}$ of chloroform and $1 \mathrm{ml}$ of concentrated $\mathrm{H}_{2} \mathrm{SO}_{4}$ were added to the solution carefully along the wall of the test tube. Presence of a reddish-brown ring at the separation level of two liquids indicated the presence of steroids.

Test for cholesterol: $2 \mathrm{ml}$ of sample extract was added with $2 \mathrm{ml}$ of chloroform. Then 10-12 drops of anhydrous $\mathrm{CH}_{3} \mathrm{COOH}$ was added and the mixture was shaken well. After that, 2 drops of concentrated $\mathrm{H}_{2} \mathrm{SO}_{4}$ was added to the solution. The change of reddish-brown color into the blue-green confirmed the presence of cholesterol.

Test for alkaloids: $2 \mathrm{ml}$ of sample solution was taken into a test tube and $2 \mathrm{ml}$ of $2 \mathrm{~N} \mathrm{HCl}$ was added to it. Then the test tube was shaken vigorously to mix that solution and kept in room temperature for 5 min. The aqueous phase was separated from the two liquid phases and then few drops of Mayer's reagent $\left(\mathrm{HgCl}_{2}+\mathrm{KI}\right.$ in water $)$ was added to it and shaken. Formation of creamy coloured precipitation indicated the presence of alkaloids.

Test for phenol: $10 \mathrm{ml}$ of the sample was added with 4-5 drops of $2 \% \mathrm{FeCl}_{3}$ solution. Changes in colouration indicated the presence of phenolic compounds.

Test for flavonoids: 2 gm of powdered material was added to $10 \mathrm{ml}$ of ethyl acetate and heated in a water bath for 5 min. After cooling, the solution was filtered and the filtrate was mixed with to $4 \mathrm{ml}$ of liquid ammonia solution (10\%) and shaken vigorously. The appearance of the yellow colouration indicated the presence of flavonoids.

Test for anthraquinone: 0.5 gm of powdered material was shaken with $20 \mathrm{ml}$ of benzene in a magnetic stirrer for $4 \mathrm{~h}$. at room temperature. The mixture was then filtered and $10 \mathrm{ml}$ of the filtrate was mixed with $0.5 \mathrm{ml}$ of $10 \%$ ammonia solution and shaken well. The presence of violet colour at the layer phase indicated the presence of anthraquinones.

Test for saponin: 0.5 gm of powdered material was added with 15 $\mathrm{ml}$ double distilled water and shaken well. Formation of intensive and persistent froth indicated the presence of saponin.

\section{Antioxidant activity of jute leaf extract \\ DPPH radical scavenging activity}

The antioxidant activity of the methanol extract of leaves of $C$. olitorius was measured on the basis of the scavenging activity of the stable 1,1-diphenyl 2-picrylhydrazyl (DPPH) free radical with slight modifications [10, 11]. Briefly, $0.1 \mathrm{mmol}$ solutions of DPPH in methanol was prepared. Then $1 \mathrm{ml}$ of this DPPH solution was added to $3 \mathrm{ml}$ of the methanolic extract at different concentrations ( 0 $\mu \mathrm{g} / \mathrm{ml}, 50 \mu \mathrm{g} / \mathrm{ml}, 80 \mu \mathrm{g} / \mathrm{ml}, 100 \mu \mathrm{g} / \mathrm{ml}, 150 \mu \mathrm{g} / \mathrm{ml}$ and $200 \mu \mathrm{g} / \mathrm{ml})$.

The mixture was then shaken well and allowed to stand for $30 \mathrm{~min}$ at room temperature. The lower absorbance of the reaction mixture indicated higher free radical scavenging activity. $\alpha$-tocopherol was used as a positive control.

\section{Statistical analysis}

All data are presented as the mean \pm SD of three measurements. Statistical analysis was performed using the KyPlot version 2.0 beta 15 (32 bit). IC 50 values were calculated using the following formula: $\mathrm{Y}=100 \times \mathrm{A} 1 /(\mathrm{X}+\mathrm{A} 1)$, where $\mathrm{A} 1=\mathrm{IC} 50, \mathrm{Y}=\operatorname{response}(\mathrm{Y}=100 \%$ when $X=0)$, and $X=$ inhibitory concentration. Differences between two groups (plant extract and standard in DPPH radical scavenging assay) were determined by a paired test. $\mathrm{p}<0.05$ was considered significant.

\section{RESULTS AND DISCUSSION}

\section{Qualitative estimation of phytochemicals}

The phytochemical screening carried on the leaf extract of Corchorus olitorius revealed the presence of some active ingredients such as alkaloids, cardiac glycosides, saponins, phenols and flavonoids. These phytochemicals are known to possess therapeutic activity which justifies its uses as traditional medicine [12]. Sharmila et al. [13] documented that these phytoconstituents may be responsible for several pharmacological activities like wound healing, cholesterol lowering and antidiabetic activity. It has been known that plant steroid, flavonoids and phenols are antioxidants.

Table 1: Comparison of presence of phytochemicals in jute (C. olitorius) leaf extract

\begin{tabular}{|c|c|c|c|}
\hline \multirow[t]{2}{*}{ Chemicals } & \multicolumn{3}{|c|}{ Presence of phytochemicals in jute leaf } \\
\hline & Immature & Mature & Senescent \\
\hline Carbohydrate & + & + & + \\
\hline Glycosides & + & + & + \\
\hline Protein & + & + & + \\
\hline Steroid & + & + & + \\
\hline Cholesterol & + & + & + \\
\hline Alkaloid & + & + & + \\
\hline Phenol & + & + & + \\
\hline Flavonoid & + & + & + \\
\hline Riboflavin & + & + & + \\
\hline Saponin & + & + & + \\
\hline Anthraquinone & - & - & - \\
\hline Tannin & - & - & - \\
\hline Phlobatannin & - & - & - \\
\hline Terpenoids & + & + & + \\
\hline
\end{tabular}




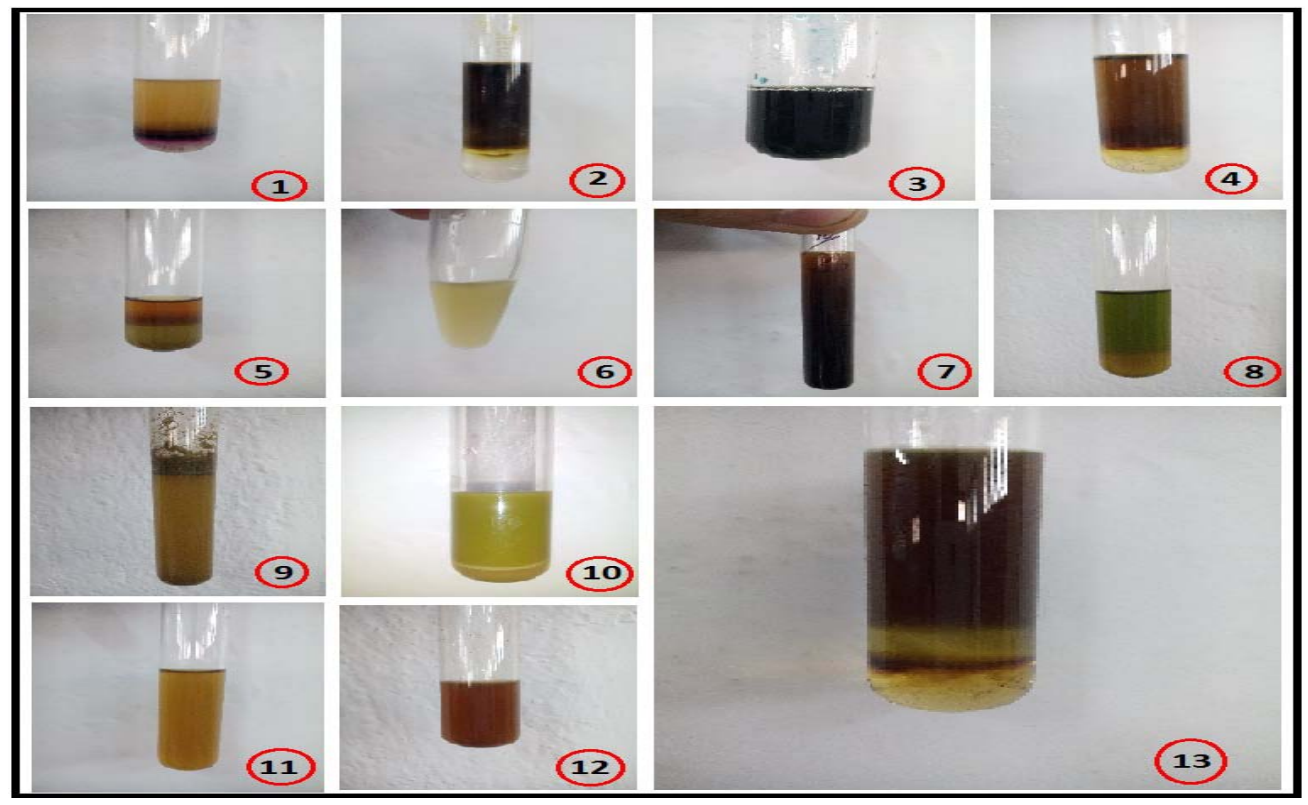

Fig. 1: Qualitative analysis of jute leaf extract, [1] Carbohydrate [ 2] Glycoside [3] Protein [4] Steroid [5] Cholesterol [6] Alkaloid [7] Phenol [8] Flavonoid [9] Saponin [10] Anthraquinone [11] Tannin [12] Phlobatannin [13] Terpenoid

\section{DPPH radical scavenging assay}

Antioxidants molecules of plants generally belong to secondary metabolic products. These molecules protect cells against the destructive effects of reactive oxygen species (ROS), such as superoxide anion $\left(\mathrm{O}_{2}^{-}\right)$, hydrogen peroxide $\left(\mathrm{H}_{2} \mathrm{O}_{2}\right)$, and hydroxyl radical (HO•) formed by the partial reduction of oxygen. Cellular ROS are generated endogenously as a normal metabolic function in the mitochondrial oxidative phosphorylation, and or they may occur due to interactions of the cell with exogenous sources such as xenobiotic compounds. An imbalance between antioxidants and ROS results in oxidative stress in cell and leading to cellular spoil [14]. This situation often linked to physiological disorders viz., cancer, ageing, atherosclerosis, inflammation, ischemic injury and neural degeneration [15].

Table 2 shows the results of the free radical (DPPH) scavenging activity in (\%) inhibition. The result revealed that the methanol extract of immature C. Olitorius leaf (60 DAS) exhibited the highest DPPH radical scavenging activity with $27.563 \pm 2.813 \%$ at $200 \mu \mathrm{g} / \mathrm{ml}$ concentration (which is nearly close to the value of $\alpha$-tocopherol i.e. $33.294 \pm 1.261 \%$ at $150 \mu \mathrm{g} / \mathrm{ml}$ ) followed by $16.513 \pm 2.813 \%$, $15.899 \pm 3.834 \%, \quad 8.533 \pm 2.813 \%$ and $4.236 \pm 3.683 \%$ at the concentrations of $150 \mu \mathrm{g} / \mathrm{ml}, 100 \mu \mathrm{g} / \mathrm{ml}, 80 \mu \mathrm{g} / \mathrm{ml}$ and $50 \mu \mathrm{g} / \mathrm{ml} \mathrm{l}$ respectively. On the other hand in case of methanolic extract of mature C. Olitorius leaf (60 DAS), the highest inhibition activity i. e $54.573 \pm 2.126 \%$ was found at $200 \mu \mathrm{g} / \mathrm{ml}$ followed by $47.206 \pm 1.063 \%$, $41.682 \pm 3.834 \%, 34.929 \pm 2.813 \%$ and $21.424 \pm 2.813 \%$ at different range of concentration of $150 \mu \mathrm{g} / \mathrm{ml}, 100 \mu \mathrm{g} / \mathrm{ml}, 80 \mu \mathrm{g} / \mathrm{ml}$ and 50 $\mu \mathrm{g} / \mathrm{ml}$ respectively. The order of percentage of scavenging activity in case of methanolic extract of senescence $C$. Olitorius leaf (60 DAS) were $63.718 \pm 2.126 \%, \quad 61.939 \pm 2.126 \%, \quad 57.642 \pm 1.841 \%, \quad 53.345 \pm 1.063 \%$ and $49.048 \pm 1.063 \%$ at different concentration levels of $200 \mu \mathrm{g} / \mathrm{ml}$ $150 \mu \mathrm{g} / \mathrm{ml}, 100 \mu \mathrm{g} / \mathrm{ml}, 80 \mu \mathrm{g} / \mathrm{ml}$ and $50 \mu \mathrm{g} / \mathrm{ml}$ respectively (table 2 and fig. 2).

Table 2: DPPH scavenging activity of $C$. Olitorius leaf (60 DAS) extract of different stages

\begin{tabular}{lllll}
\hline Concentration of extracts $(\boldsymbol{\mu g} / \mathbf{m l})$ & \multicolumn{3}{l}{ Antioxidant activity $\mathbf{( \% )}$} \\
\cline { 2 - 5 } & $\boldsymbol{\alpha}$-tocopherol & \multicolumn{3}{l}{ Methanolic leaf extract of $\boldsymbol{C}$. Olitorius (60 DAS) } \\
\cline { 2 - 5 } & & Immature & mature & Senescence \\
\hline 50 & $10.955 \pm 0.761$ & $4.236 \pm 3.683$ & $21.424 \pm 2.813$ & $49.048 \pm 1.063$ \\
80 & $14.893 \pm 0.779$ & $8.533 \pm 2.813$ & $34.929 \pm 2.813$ & $53.345 \pm 1.063$ \\
100 & $20.663 \pm 1.355$ & $15.899 \pm 3.834$ & $41.682 \pm 3.834$ & $57.642 \pm 1.841$ \\
150 & $33.294 \pm 1.261$ & $16.513 \pm 2.813$ & $47.206 \pm 1.063$ & $61.939 \pm 2.126$ \\
200 & $42.612 \pm 1.123$ & $27.563 \pm 2.813$ & $54.573 \pm 2.126$ & $63.718 \pm 2.126$ \\
\hline
\end{tabular}

『Data presented as mean \pm SD of three independent observations, significantly less $\mathrm{IC}_{50}$ value $75.41 \pm 5.25 \mu \mathrm{g} / \mathrm{ml}$ was observed in methanolic extracts of senescence $C$. Olitorius leaf ( 60 DAS) in comparison to $327.35 \pm 7.10 \mu \mathrm{g} / \mathrm{ml}$ obtained in the methanolic extract of the standard $\alpha$-tocopherol. IC 50 values of mature and immature leaf extract were recorded as $159.57 \pm 14.55$ and $633.26 \pm 46.36$ respectively.

Senescence $C$. Olitorius leaf (60 DAS) extract shows the highest scavenging activity followed by the mature and immature leaf $(60$ DAS) extract. Tiwari et al. [16] reported that Methanol is an efficient solvent to extract phenolic compounds. In the present study, it was observed that the $\mathrm{IC}_{50}$ values were increased with increase in the concentration of crude extracts which may be indicated that antioxidant values may be dependent on the presence of different phytochemicals such as phenols, alkaloids, flavonoids, saponins, tannins etc. Trease et al. [17] and Warrier et al. [18] evicted that that phenolic compounds are responsible for the variation in the antioxidant activity of the plant. It has been determined that the antioxidant effect of plant products is mainly due to radical scavenging activity of phenolic compounds such as alkaloids, flavonoids, phenols and tannins $[19,20]$. 


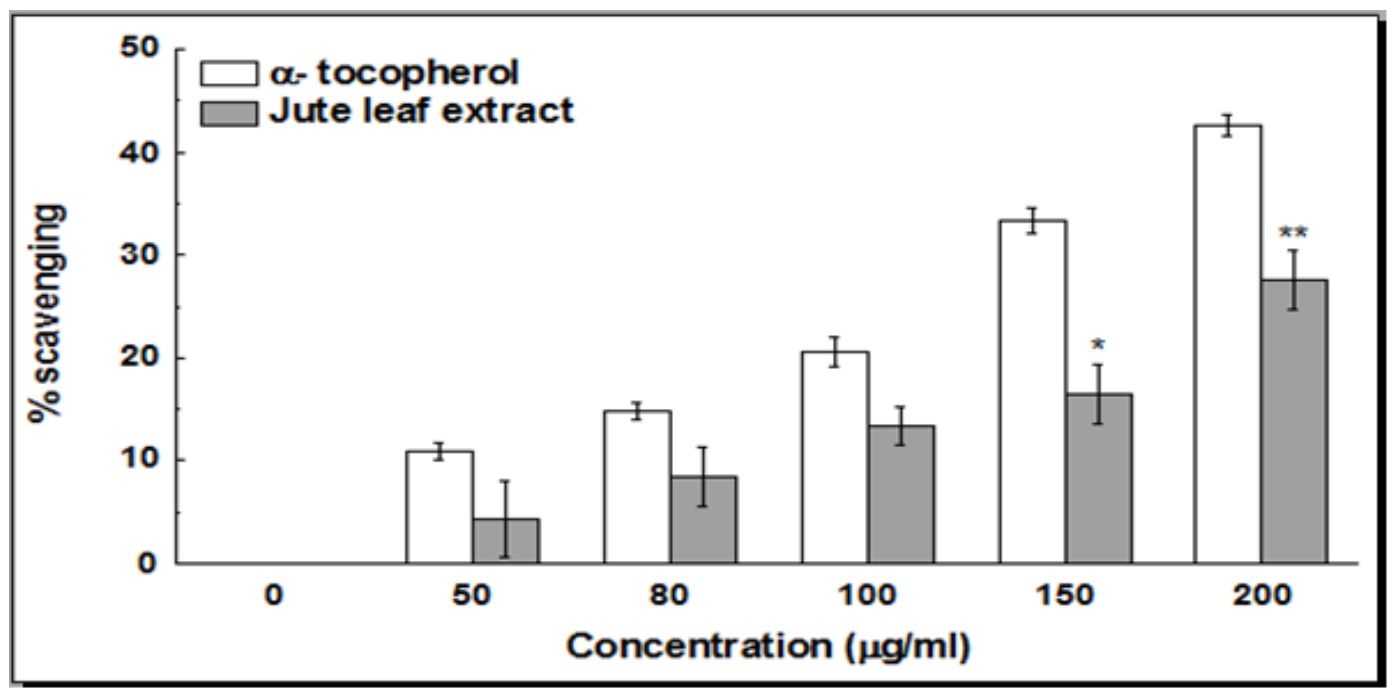

Fig. 2a: DPPH radical scavenging activity of methanolic leaf extract of Corchorus olitorius (Immature, 60DAS) $\left({ }^{*} \mathbf{p}<0.01,{ }^{* *} \mathbf{p}<0.001\right.$ and $* * * \mathrm{p}<0.0001$ ) $\mathrm{IC}_{50}$ value $633.26 \pm 46.36 \mu \mathrm{g} / \mathrm{ml}$

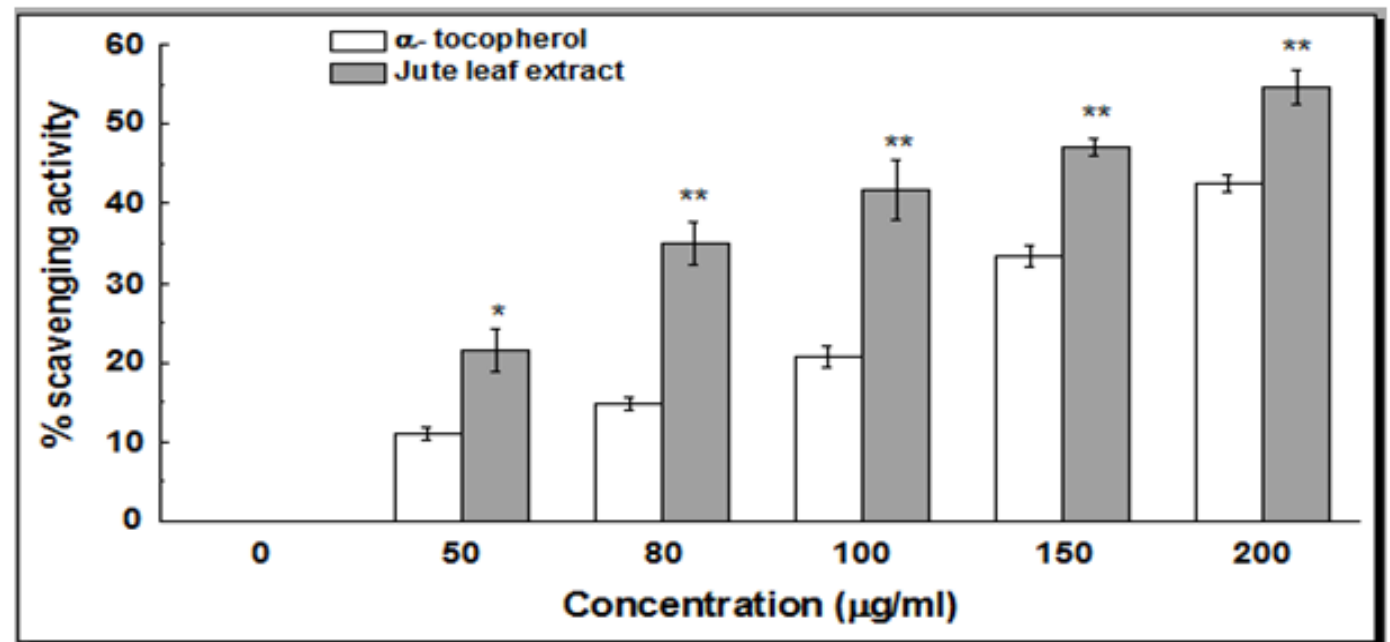

Fig. 2b: DPPH radical scavenging activity of methanolic leaf extract of Corchorus olitorius (Mature, 60DAS) $\left({ }^{*} \mathbf{p}<0.01,{ }^{* *} \mathbf{p}<0.001\right.$ and $* * * \mathrm{p}<0.0001$ ) IC50 value $159.57 \pm 14.55 \mu \mathrm{g} / \mathrm{ml}$

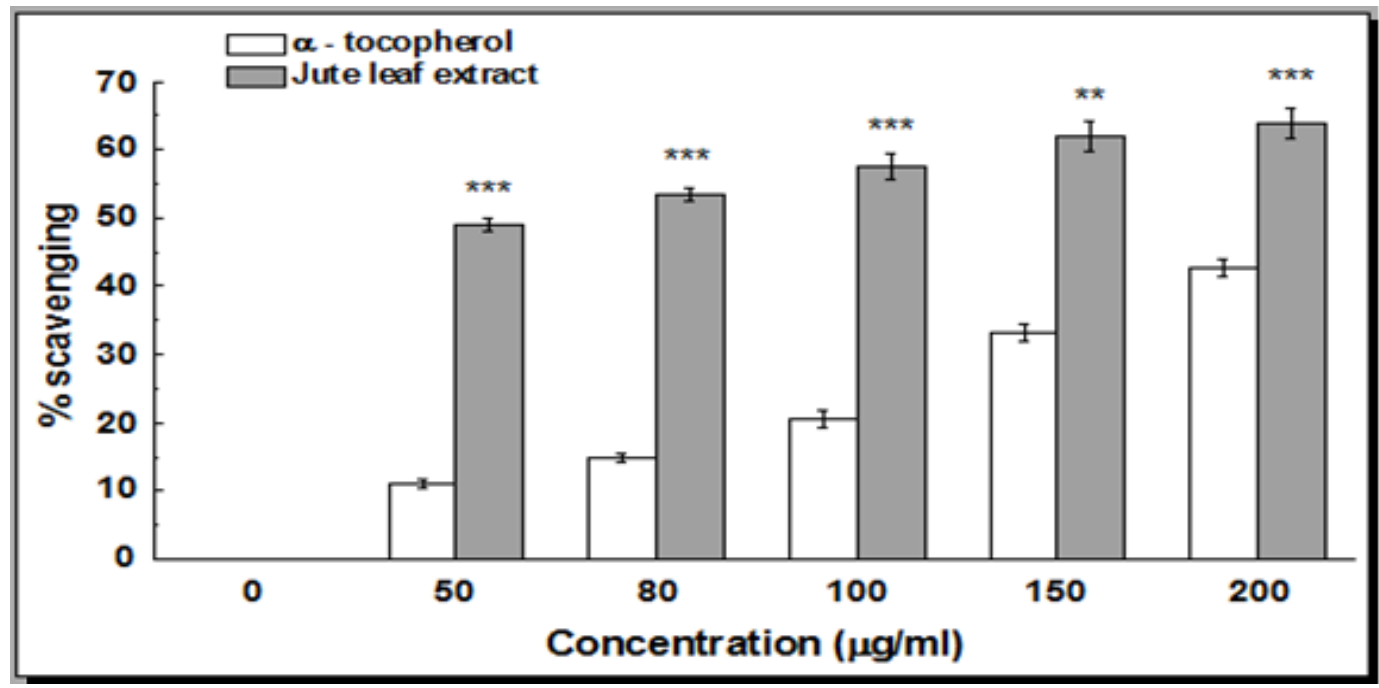

Fig. 2c: DPPH radical scavenging activity of methanolic leaf extract of Corchorus olitorius (Senescence, 60DAS) $\left({ }^{*} \mathrm{p}<0.01,{ }^{* *} \mathrm{p}<0.001\right.$ and ${ }^{* * *} \mathrm{p}<0.0001$ ) IC So $_{5}$ value $75.41 \pm 5.25 \mu \mathrm{g} / \mathrm{ml}$ 


\section{CONCLUSION}

The present study of phytochemical screening and antioxidant activity of methanolic extract of leaves of Corchorus olitorius indicated the presence of different secondary metabolites and antioxidants. The presence of these bioactive compounds in jute leaf establishes it as a potential source of a natural therapeutic agent that can be used against different infectious and other diseases. $C$. olitorious is easily available and economically cheap and therefore can be used for the medicinal purposes. Finally, investigations on the isolation and identification of antioxidant components in this particular plant will lead us to know the chemical entities with potential for clinical use.

\section{CONFLICT OF INTERESTS}

The author declares that they have no conflict of interest.

\section{REFERENCES}

1. Niki E, Shimaski H, Mino M. Antioxidantism-free radical and biological defence. Gakkai Syuppn Center. Tokyo: Japan; 1994. p. 3-16.

2. Roy S, Hazra B, Mandal N, Chaudhuri TK. Assessment of the antioxidant and free radical scavenging activities of methanolic extract of Diplazium esculentum. Int J Food Prop 2013; 16:1351-70.

3. FAO. FAO Statistics, Food and Agriculture Organizations, United Nations; 2011.

4. Islam MM. Biochemistry, medicinal and food values of jute (Corchorus capsularis L. and C. olitorius L.) leaf: a review. Int J Enhanced Res Sci Tech Eng 2013;2:35-44.

5. Islam MM. Jute (Corchorus capsularis L. and C. olitorius L.) leaf: Vegetable for nutrition and medicine for human health and beauty; 2012. Available from: http://www.purejute.com/ images/stories/purejute/pure_jute/publicaties/jute_leaf.pdf) [Last accessed on 10 Apr 2017].

6. Brain KR, Turne TD. The practical evaluation of phytopharmaceuticals. Bristol Sci 1995;13:978.

7. The Indian Pharmacopoeia. $4^{\text {th }}$ edition. $2^{\text {nd }}$ Vol. The controller of publication, Govt. of India; 1996.
8. Khandelwal KR. Practical pharmacognsoy. Nirali prakasan, India; 2008.

9. Gokhale SB, Kokate CK. Practical pharmacognsoy. Nirali prakasan, India; 2008.

10. Blois MS. Antioxidant determinations by the use of a stable free radical. Nat Protoc 1958;29:1199-200.

11. Ulyana A, Daniel E, Michel H, Edward J, Kennelly S. Antioxidant activity of browning reaction prepared from glucosamine. Phytother Res 2002;16:63-65.

12. Lachman L, Lieberman HA, Kanig J. The theory and practice of Industrial pharmacy. Edn 3. New York: Varghese publishing house; 1989. p. 293-373.

13. Shrmila BG, Kumar G, Rajasekhara PM. Cholesterol lowering activity of the aqueous fruit extract of Trichosanthes dioica Roxb. in normal and streptozotocin diabetic rats. J Clin Diagn Res 2007;1:561-9.

14. Siddique AA, Alim A. Practical pharmaceutical chemistry. Edn 1. New Delhi: CSB Publishers and distributors; 1997. p. 126-31.

15. Sofowora A. Medicinal plants and traditional medicine in Africa. New York: John Wiley and Sons; 1993. p. 191-289.

16. Tiwari P, Kumar B, Kaur M, Kaur G, Kaur H. Phytochemical screening and extraction: a review. Int Pharm Sci 2011;1:98-106.

17. Trease GE, Evans WC. Pharmacognosy. Edn. 11. Brailliar Tiridel Can. Macmillian Publishers; 1989.

18. Warrier PK, Nambiar VPK, Ramankutty C. Indian Medicinal Plants. Vol. 5. Orient Longman Ltd. Madras; 1995.

19. Rice-Evans CA, Miller NJ, Paganga G. Antioxidant properties of phenolic compounds. Trends Plant Sci 1997;2:152-9.

20. Raaman N. Antioxidant activities and phytochemical analysis of methanol extract of leaves of hygrophila auriculata (schumach) heine. Int J Curr Pharm Res 2015;7:100-5.

\section{How to cite this article}

- Abdul Sadat, Mayukh Hore, Kaushik Chakraborty, Subhrajyoti Roy. Phytochemical analysis and antioxidant activity of methanolic extract of leaves of Corchorus olitorius. Int J Curr Pharm Res 2017;9(5):59-63. 